\title{
FEET STATUS IN FOOTBALL PLAYERS OF DIFFERENT COMPETITION CATEGORIE
}

\author{
Dejan Ilić ${ }^{1}$, Stefan Stojaković ${ }^{1}$, Nikola Fišeković ${ }^{1}$, and Saša Đurić ${ }^{1}$ \\ ${ }^{1}$ Faculty of Sport and Physical Education, University of Belgrade, Serbia
}

\section{SUMMARY}

\begin{abstract}
Medical check-up shave determined an increasing number of children with body defects as well as functional disabilities of locomotors system. Therefore it is essential to involve children in various forms of physical activities. In that sense, one of the most successful measures to implement in order to act preventively, and consequently correctively, are the sports games. Modern way of life leads to many postural disorders and deformities and one of the most presenting schoolchildren is flatfeet. The aim of the paper is detections well as presentation of feet postural status of football players of different competition categories in Valjevo football clubs. This search included 114 children playing for football clubs of Valjevo, and indicated the fact of lower percentage of children with flatfeet $(40.35 \%)$, than the children with no deformities (59.65\%). Additionally, the data showed that tighter percentage of children with regular feet belongs to senior categories, which are, on one side, alarm in data since they indicate that younger children have higher percentage of deformities and weaker posture, but on the other hand this fact is encouraging because such deformities are eliminated with more success at young age. It is necessary to promptly implement prophylaxis, especially in critical periods for flatfeet occurring. Thus, the deformities can be duly treated. Initially, the exercises performed at football training are not aimed at correction of a deformity, but as means of football game. But, when analyzed in details we can see that they have significant preventive action for certain body parts..
\end{abstract}

Key Words: competition categories, correction, feet status, football, prevention.

\section{INTRODUCTION}

Today, modern men live in predominantly urbanized and technologically developed society. Having in mind our biological background that adapted us to more active life style (hunting, food search and other needs) we should, for our own good, influence our modern lifestyle (llić, 2006).

Medical check-ups indicate that, besides bad posture, an increasing number of children suffer from body deformities as well as functional disabilities of locomotors system based on certain diseases (Radisavljević, 2001).

Understanding this, it is clear that physical exercises, when adequately implemented, together with all precautions, can be one of the most efficient and most useful measures to correct such states. Thus, physical exercises should be understood as basic means of kinesitherapy and therefore, of corrective gymnastics as its integral part (Koturović \& Jeričević, 1996).

Sports games are one of more successful methods of corrective gymnastics. They are applied in order to undertake precautions to improve physical and functional abilities as well as to undertake measures for complete rehabilitation, i.e. re-socialization of those who have already developed disease, defect or deformity (Radisavljević, 2001).

Statistical analyses indicate that most frequent disorders and deformities of locomotor system in schoolchildren refer to different forms and stadiums of fallen arches (Kosinac, 2008). Incidence of this deformity is caused, or at least contributed by modern way of life. Using transportation means leads to less activities of feet musculature which in children is in development. Therefore, movement is particularly 
important because it causes progress of muscular quality decrease (Koturović \& Jerinčević, 1996).

\section{METHODS}

\section{Simple of subject}

The research included 114 children playing for football clubs of Valjevo. They were classified according to training categories and include children aged 10 - 18yrs.

The research was done in March 2013, and statistical and descriptive methods were used for paper

\section{Simple of variables}

The research involved the feet status variable, determined by plantography method. Plantograms were interpreted and data were obtained by the method of Russian authors (Figure 1). According to this method, the plantogram in the front part of foot, at the level of the first and fifth metatarsal bone and at the level of the fifth is divided into five equal sections. If the footprint, seen from the lateral towards medial part, does not exceed $2 / 5$ of the plantogram i.e. two of the five drawn sections, that is considered good feet status. Should the footprint cover $3 / 5$ of the platnogram, that indicates the first degree, $4 / 5$ is

\section{FIGURE 1}

Plantogram interpretation by the method of Russian authors.

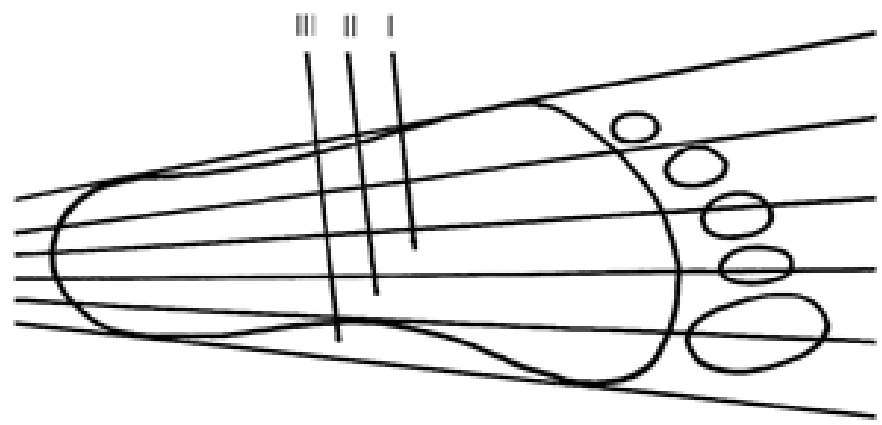

Legend: I - 1st degreeof fallen arches; II - 2nd degreefallen arches; III - 3rd degreefallen arches.

the second degree while $5 / 5$ signifies the third degree of fallen side arches (Ilić, 2012).

\section{RESULTS AND DISCUSSON}

Upon statistical elaboration, the data were shown in tables and graphs, with conclusion.

TABLE 1

Number and percentage of participants with flat feet.

\begin{tabular}{lcr}
\hline \multicolumn{1}{c}{ Sample } & $\mathrm{n}$ & \multicolumn{1}{c}{$\%$} \\
\hline Overall & 114 & 100.00 \\
\hline Regular feet & 68 & 59.65 \\
\hline Falt feet & 46 & 40.35 \\
\hline
\end{tabular}

Legend: $\mathbf{n}$ - Number of participants; $\%$ - Percentage.

The data were further analyzed in Table 2 and presented by Figure 3 and indicate that regular left foot status occurred in 71 participant (i.e. 62.28\%),
Based on the results displayed in Table 1 and Figure 2 we can conclude that regular feet status occurred in 68 participants i.e., $59.65 \%$, while physiologically fallen arches occurred in 46 participants i.e. $40.35 \%$ of the overall number of examined football players.

\section{FIGURE 2}

Number and percentage of participants with flat feet.

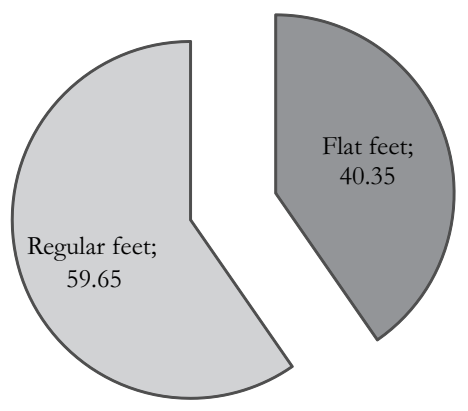

that 1 st degree occurred in 32 (i.e. $28.07 \%$ ), 2nd degree in 11 (i.e. 9.65\%), while the 3rd degree of fallen arch was not detected in any of the participants. 
TABLE 2

Number of participants with regard to degree of left foot fallen arches.

\begin{tabular}{lcccc}
\hline & $\begin{array}{c}\text { Regular left } \\
\text { feet status }\end{array}$ & $\begin{array}{c}\text { 1st degree of } \\
\text { fallen arches }\end{array}$ & $\begin{array}{c}\text { 2nd degree } \\
\text { fallen arches }\end{array}$ & $\begin{array}{c}\text { 3rd degree } \\
\text { fallen arches }\end{array}$ \\
\hline $\begin{array}{l}\text { Number of } \\
\text { participants }\end{array}$ & 71 & 32 & 11 & 0 \\
\hline
\end{tabular}

\section{FIGURE 3}

Percentage of participants with regard to degree of left foot fallen arches.

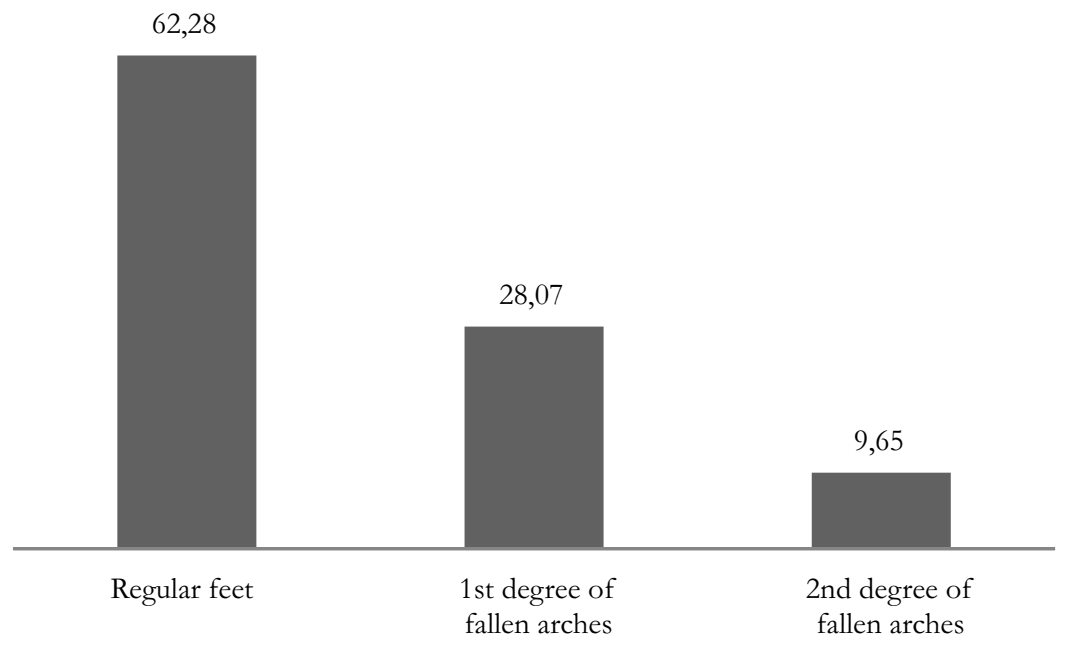

Table 3 as well as Figure 4 display the level of right degree occurred in 26 (i.e. 22.80\%), second degree in foot fallen arches. The data indicated that regular right 11 (i.e. 9.65\%), while the 3rd degree of fallen arch foot occurred in 77 participants (Tj. 67.55\%), that first was not detected in any of the participants.

TABLE 3

Number of participants with regard to degree of right foot fallen arches.

\begin{tabular}{lcccc}
\hline & $\begin{array}{c}\text { Regular left } \\
\text { feet status }\end{array}$ & $\begin{array}{c}\text { 1st degree of } \\
\text { fallen arches }\end{array}$ & $\begin{array}{c}\text { 2nd degree } \\
\text { fallen arches }\end{array}$ & $\begin{array}{c}\text { 3rd degree } \\
\text { fallen arches }\end{array}$ \\
\hline $\begin{array}{l}\text { Number of } \\
\text { participants }\end{array}$ & 77 & 26 & 11 & 0 \\
\hline
\end{tabular}

\section{FIGURE 4}

Percentage of participants with regard to degree of right foot fallen arches.

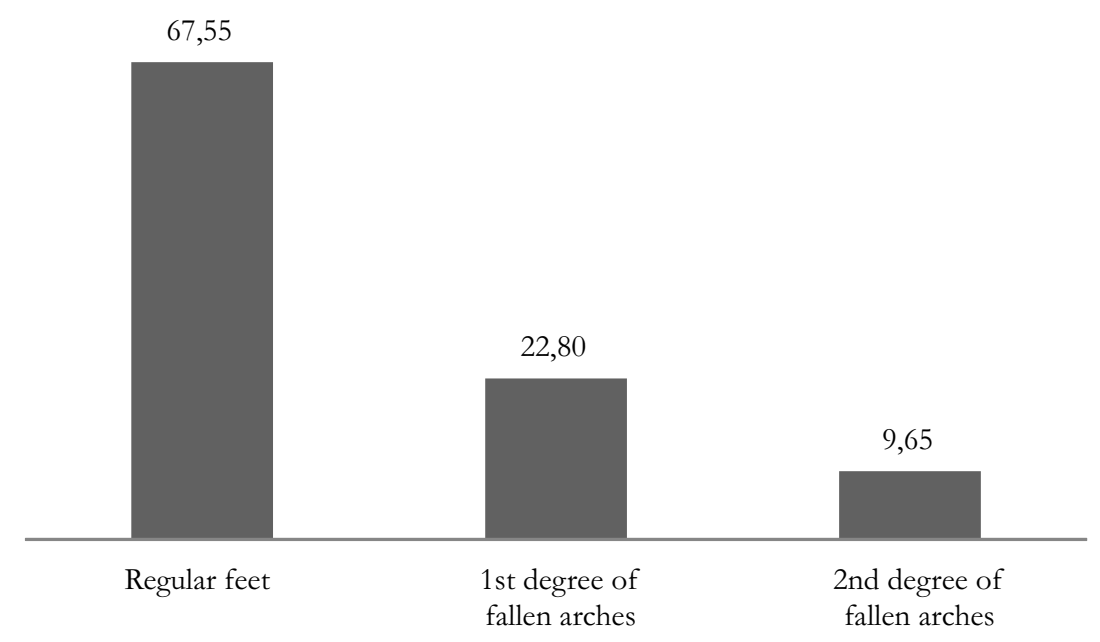


Table 4, as well as Figure 5 present the number and percentage of participants with flat feet according to the competition categories. It was established that the 1st degree of fallen arches occurred most with children aged $7-10,53.33 \%$, and the 2nd degree of fallen arches occurred most in children aged 11-12, $14.82 \%$. The highest percentage or regular feet occurred in cadets $(70.59 \%)$, and the lowest in players aged 7 to $10(40.00 \%)$.

\section{TABLE 4}

Number of participants with regard to feet status according to competition categories.

\begin{tabular}{lccccc}
\hline Feet status & $\mathrm{n}$ & $\mathrm{RF}$ & $\mathrm{I}$ & $\mathrm{II}$ & $\mathrm{III}$ \\
\hline Aged 7-11 & 15 & 6 & 8 & 1 & 0 \\
\hline Aged 11-12 & 27 & 12 & 11 & 4 & 0 \\
\hline Pioneers & 25 & 17 & 6 & 2 & 0 \\
\hline Cadets & 34 & 24 & 7 & 3 & 0 \\
\hline Youths & 13 & 9 & 3 & 1 & 0 \\
\hline Overall & 114 & 68 & 35 & 11 & 0 \\
\hline
\end{tabular}

Legend: $\mathbf{n}$ - Number of participants; RF - Regular foot; I - 1 st degreeof fallen arches; II -2 nd degreefallen arches; III - 3rd degreefallen arches.

\section{FIGURE 5}

Percentage of participants with regard to feet status according to competition categories.
Regular feet
$\square$ st degree of fallen arches
$\square$ 2nd degree of fallen arches

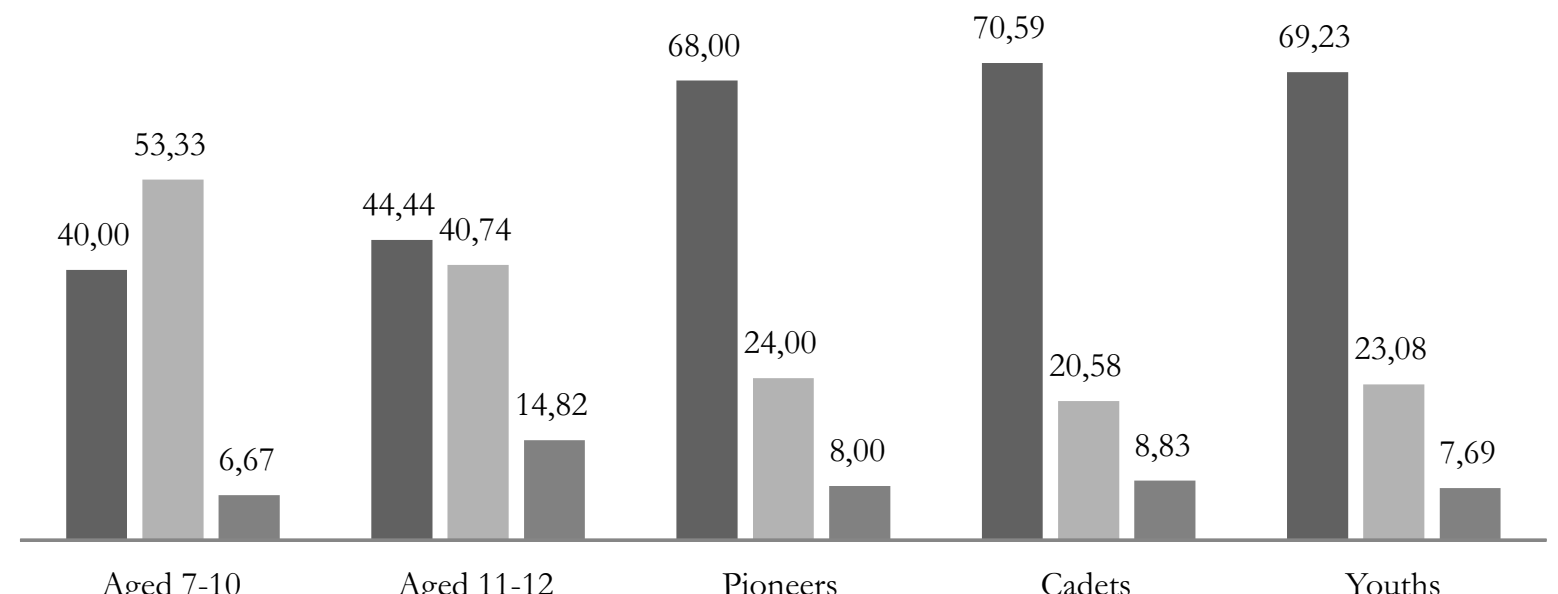

Aged 7-10

Aged 11-12

Pioneers

Cadets

Youths

The data were further analyzed in Table 5 and established that $66.67 \%$ of them live in urban envigraphically in Figure 6, showing the number of par- ronments and only 33.33\% of them are from rural ticipants with regard to place of residence. It was

\section{TABLE 5}

Number and percentage of participants with regard to residence.

\begin{tabular}{ccc}
\hline Residence & $\mathrm{n}$ & $\%$ \\
\hline Urban environment & 76 & 66.67 \\
\hline Rural environment & 38 & 33.33 \\
\hline
\end{tabular}

Legend: $\mathbf{n}$ - Number of participants; $\mathbf{0}$ - Percentage. environments.

\section{FIGURE 6}

Percentage of participants with regard to residence.

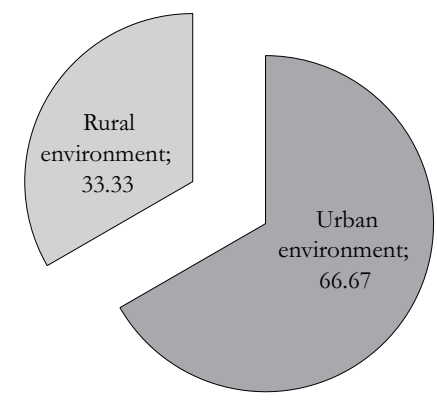


Table 6 and Figure 7 display the degree of fallen arches with regard to children's residence (urban vs. rural environment). The data show that greater percentage of participants with regular feet status live in rural environment $68.42 \%$. The first degree of fallen arches was more represented in participants from urban environment (35.52\%), while the 2nd degree of flat feed occurred more in participants from rural environment $(10.53 \%)$.

TABLE 6

Number of participants with flat feet regard to residence.

\begin{tabular}{lccccc}
\hline & $\begin{array}{c}\text { Number of } \\
\text { participants }\end{array}$ & $\begin{array}{c}\text { Regular } \\
\text { feet status }\end{array}$ & $\begin{array}{c}\text { 1st degree of } \\
\text { fallen arches }\end{array}$ & $\begin{array}{c}\text { 2nd degree } \\
\text { fallen arches }\end{array}$ & $\begin{array}{c}\text { 3rd degree } \\
\text { fallen arches }\end{array}$ \\
\hline $\begin{array}{l}\text { Urban } \\
\text { environment }\end{array}$ & 76 & 42 & 27 & 7 & 0 \\
\hline $\begin{array}{l}\text { Rural } \\
\text { environment }\end{array}$ & 38 & 26 & 8 & 4 & 0 \\
\hline
\end{tabular}

FIGURE 7

Percentage of participants with flat feet with regard to residence.

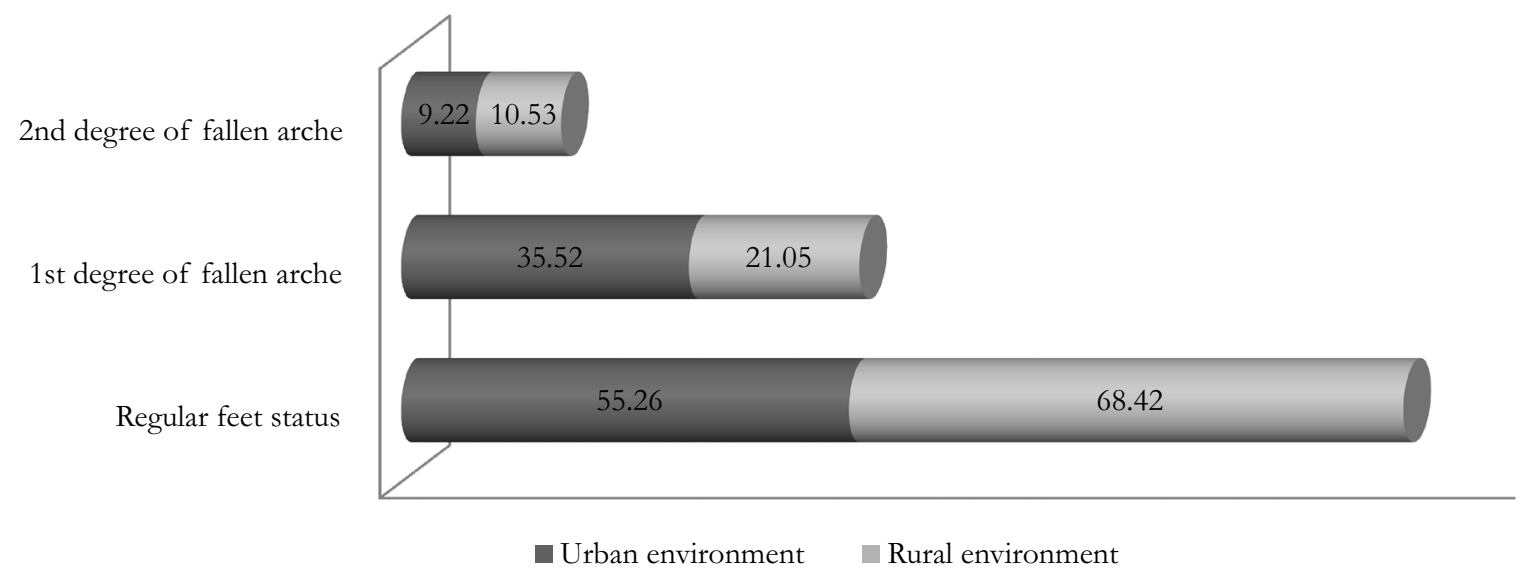

\section{CONCLUSON}

The results of the research indicate that 59,65\% participants have regular physiological feet status, without signs of a possible deformity occurrence.

Flat feet most occur at the age of 10-12 years (first two categories), followed by pioneers 13-14 years, 18 -year old youth, while it occurred most rarely in cadets aged $15-17$ years.

Feet deformities such as flat feet occurred more in children from urban environment $66.67 \%$, then in those who grew up in rural environment $33.33 \%$.

We can conclude that the percentage of participants with 1 st degree of fallen arches in urban environment was $35.52 \%$, while in rural environment that percentage was much lower $21.05 \%$. The 2 nd degree of fallen arches occurred in urban environment in $9.22 \%$, while in rural environment that percentage was slightly higher and amounts to $10.53 \%$.

The obtained results indicate that it is necessary to implement all possible prevention measures in order to prevent further progression of feet status deterioration and football is surely sports game, which according to its features, is very appropriate for application of therapeutic influence. Children can be motivated through different elementary games, and additionally by placing specific tasks, it can result in elimination of certain deformities. The application of different skips (frontal, side), starting from ladders, rolling, ball carrying represents exercises that contribute to adequate formation of bone and muscle- ligament foot structure. It is necessary to focus on regular position in of feet, to teach children about regular body posture while taking certain positions in order to distribute evenly load sand not to overload some foot bone and muscle structures. Surely, it is good that children walk bare foot for some part of training, if the reare adequate conditions that would not damage children's health.

It is of utmost importance to implement feet controls and consequently implement corrective treat- 
ments. Such treatments imply applications of movements for preventive and corrective purposes.

\section{REFERENCES}

Ilić, D. (2012). Korektivna gimnastika [Corrective gymnastics]. Belgrade, Serbia: Faculty of Sport and Physical Education.

Ilić, N. (2006). Fiziologija sporta [Physiology of Sport]. Belgrade; Serbia: SIA.
Kosinac, Z. (2008). Kineziterapija sustava za kretanje [Kinesitherapy of the locomotor system]. Zagreb, Croatia: Gopal.

Koturović, LJ., \& Jeričević, D. (1996). Korektivna gimnastika [Corrective gymnastics]. Belgrade; Serbia: IGP „MIS SPORT“.

Radisavljević, M. (2001). Korektivna gimnastika sa osnovama kineziterapije [Corrective gymnastics and elements of kinesitherapy]. Belgrade, Serbia: Advanced school for sports coaches.

Received: October 4, 2014

Revision received: Jun 21, 2015

Accepted: Jun 21, 2015

Correspondence to:

Dejan Ilić, PhD

Faculty of Sport and Physical Educaton

Blagoja Parovića 56

11000 Belgrade

Serbia

Phone: 00387642447720

E-mail: dejan.ilic@fsfv.bg.ac.rs 